九州大学学術情報リポジトリ

Kyushu University Institutional Repository

\title{
A Systematic Study of the Japanese Pipunculidae (Diptera) : Part IV. The Genus Pipunculus Latreille
}

Morakote, Rut

Entomological Laboratory, Faculty of Agriculture, Kyushu University

Hirashima, Yoshihiro

Entomological Laboratory, Faculty of Agriculture, Kyushu University

https://doi.org/10.5109/23898

出版情報：九州大学大学院農学研究院紀要. 34 (3)，pp.215-239，1990-02. Kyushu University バージョン：

権利関係 : 


\title{
A Systematic Study of the Japanese Pipunculidae (Diptera) Part IV. The Genus Pipunculus Latreille*
}

\author{
Rut Morakote and Yoshihiro Hirashima \\ Entomological Laboratory, Faculty of Agriculture, \\ Kyushu University, Fukuoka 812, Japan \\ (Received March 31, 1989)
}

\begin{abstract}
Twelve species of the Japanese Pipunculus Latreille are treated with key to species, descriptions and illustrations of important diagnostic characters. Four of them are newly recorded from Japan and seven of them are new species.
\end{abstract}

\section{Genus PIPUNCULUS Latreille}

Dorilas Meigen, 1800, Nouv. Class. Mouches: 31 . Type species : Pipunculus campestris Latreille, by subsequent designation of Coquillett (1910:35). Suppressed by I. C. Z. N. 1963. Opinion $678: 939$.

Pipunculus Latreille, 1802, Hist. Nat. Crust. Ins., 3 : 463. Type species : Pipunculus campestris Latreille, by monotypy.

The flies of this genus are characterized by having the propleural fan and the dorsum of the thorax densely clothed with short pubescence which is not differentiated on each dorsocentral line. To date, only one species has been recorded from Japan, Pipunculus boharti Hardy (1948). At present, we found eleven more species, including eight new species and four newly recorded species. The Japanese Pipunculus generally has the shining black body which is densely covered with short pubescence. The abdominal segment 8 of males is generally large and being occupied with a membranous area of varying shape. This membranous area is good for species recognition.

The hosts of this genus have been reported by many authors and they parasitized the homopterous insect of the family Cicadellidae (Coe, 1966 ; Waloff, 1975 ;Freytag, 1986).

Key to known males of Japanese PIPUNCULUS

1. Membranous area on upperpart of tergite 8 narrow, slot-like shape $\cdots \cdots \cdots \cdots \cdots \cdot \cdots \cdot 2$

- Membranous area on upperpart of tergite 8 round or oval shape $\cdots \cdots \cdots \cdots \cdots \cdots$

2. Third antennal segment yellow ; femora entirely yellow; tergite 8 (Fig. $49 \mathrm{~A}-\mathrm{C})$ much larger than 5 ; genitalia as shown in Fig. 55A-F

P. subvaripes Morakote, sp. n.

*Contribution from the Entomological Laboratory, Faculty of Agriculture, Kyushu University, Fukuoka (Ser. 3, No. 304) 
Third antennal segment black

Membranous area of tergite 8 with a conspicuous vertical middle keel

(Fig. 48A-C); femora mainly black except extreme one-seventh base and tip yellowish ; tibiae with dark marking at middle third posteriorly, genitalia as shown in Fig. 53A-D …...... P. magnicarinatus Morakote, sp. n. Membranous area of tergite 8 (Fig. 49E-G) with inconspicuous small keel at apex ; femora extensively yellow but with conspicuous broad black ring from middle to near tip ; tibiae entirely yellow ; genitalia as shown in Fig. 54A and B a................................ P. uaripes Meigen Legs almost entirely black except apical tip of femora and basal third of tibiae ; tergite 8 (Fig. 50A) almost as long as tergite 5, roughly triangular shape, membranous area of tergite 8 oval in shape; genitalia as shown in Fig. 50B-D

P. oldenbergi Collin

Legs mainly yellow except coxae and femora blackish; tibiae with brownish mark at middle third posteriorly ; tergite 8 (Fig. 51A, B and D) rather small, about one half as long as tergite 5 ; membranous area of tergite 8 rather large rounding anteriorly, about half as wide as tergite 8 ; genitalia as shown in Fig. $52 \mathrm{~A}-\mathrm{E}$................. thomsoni Becker

\section{Key to females of Japanese PIPUNCULUS}

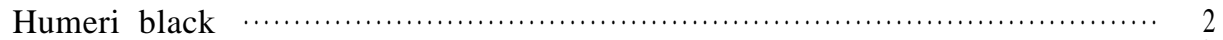

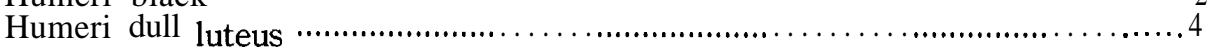

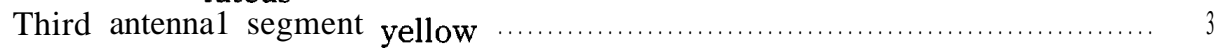

Third antenna1 segment brownish black, shortly pointed; femora almost entirely black except base and tip yellowish; trochanters brownish ; tibiae and tarsi brownish black except basal third of tibiae yellowish ; ovipositor (Fig. 59D and E) base oval, shining black ; piercer strong, almost straight, very slightly longer than base

Femora entirely yellow; third antennal segment oval ; wings rather clear, noticeably broadened, last section of vein Ml very undulating ; ovipositor (Fig. 57G and H) base oval, shining brownish black ; piercer very thin in lateral view, yellowish, about 1.3 times as long as base, very slightly downcurved …............................. Femora mainly brownish black except one-third of base and tip yellowish ; third antennal segment shortly pointed ; ovipositor (Fig. 60C and D) base conical shape, shining black; piercer rather thick, yellowish, strongly downcurved, about 1.3 times as long as base

P. rarus Morakote, sp. n.

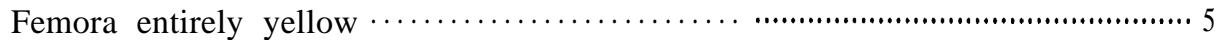

Femora mainly brownish black to black except base and tip yellowish $\cdots \cdots \cdots \cdots$ Ovipositor piercer (Fig. 57C) slightly longer than base (about 1.1-1.2 times as long as), rather thick and strongly downcurved ; third costal section of wing about 1.3 times as long as fourth 
Ovipositor (Fig. 58C and D) rather long, slender (about 1.5 times as long as base), moderately downcurved ; third costal section of wing about 1.5 times as long as fourth .............................. P. avius Morakote, sp. n. Third costal section of wings about as long as fourth $\ldots \ldots \ldots \ldots \ldots \ldots \ldots \ldots \ldots \ldots$ Third costal section of wings longer than fourth Ovipositor base conical shape, rather flat below ; piercer slightly longer than base (Fig. 60A and B) P. campestris Latreille Ovipositor (Fig. 57B) base oval shape ; piercer in lateral view strongly downcurved as that of P.subvaripes but different in ventral position as follows : broadly parallel-sided from its base to about two-thirds and then suddenly tapering to apex P. varipes Meigen Ovipositor (Fig. 58A and B) piercer very long, at least twice as long as base, moderately downcurved, third costal section of wings about twice as long as fourth ..................................... diuteus Morakote, sp. $\mathrm{n}$.

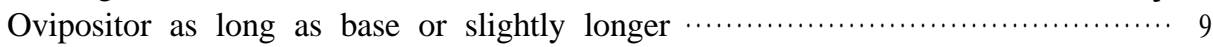
Ovipositor piercer rather thick, straight, shining brownish black, about 1.3 times as long as base ; pulvilli enlarged, about twice as long as last tarsal segment (Fig. 59A and B) .................... nitor Morakote, sp. $\mathrm{n}$. Ovipositor piercer as long as base, rather thin, wavy when seen from side ; pulvilli as long as last tarsal segment (Fig. 57F)

P. magnicarinatus Morakote, sp. n.

\section{Pipunculus varipes Meigen}

Pipunculus varipes Meigen, 1824, Syst. Beschr., $4: 21$. — Verrall, 1901, Brit. Flies, 8 : 96. — Lundbeck, 1922, Diptera Danica, $4: 33$. -Coe, 1966, Handbk. Ident. Brit. Ins., 10(2C): 50, 53. Kozanék, 1981, Annot. zool. bot. Bratislava, $142: 14$. Pipunculus monticola Schumme1, 1837, Uebers. Arb. schles. Ges. Vaterl. Kult. 1836(1837): 86 .

\section{Male.}

Eyes joined for distance about the length of frontal triangle ; frontal triangle and face silvery pubescence ; antennae all brownish black, third segment oval.

Thorax mainly shining black, with obscurely brownish dusting, densely covered with very short pale fine hairs; scutellum entirely covered with brownish dusting ; humeri black.

Legs with black coxae; femora (Fig. 49H) mainly brownish black, except basal third and apical seventh tip yellow ; trochanters, tibiae and tarsi yellow ; last tarsal segments black; hind trochanters triangular hook-like shape below as seen from side ; all femora with two parallel rows of small black spines beneath from near base to tip on mid femora, from middle to tip on front and hind femora, pulvilli slightly smaller than last tarsal segment.

Wings hyaline, stigma brownish, extending back to tip of $\mathrm{Sc}_{\mathrm{c}}$, about twice as long as fourth costal section; $\mathrm{r}-\mathrm{m}$ situated slightly before basal third of discal medial cell.

Abdomen as shown in Fig. 49E-G; densely covered with short pale hairs ; tergite 1 entirely greyish; tergites 2-5 mainly shining black, but with narrow transverse 
streaks of brownish dusting anteriorly which is never more than half of segment; tergite 8 black, with obscurely brownish dusting, about as long as tergite 5, with narrow slot-like membranous area ; this area with a distinct keel apically.

Genitalia as shown in Fig. 54A and B.

Length : Body $4.5 \mathrm{~mm}$; wing $5.5 \mathrm{~mm}$.

\section{Female.}

Frons wide, slightly convex at middle, entirely cinereous, with a row of short pale hairs along each lateral margin ; dark ring at middle of femora paler than in male ; abdomen with entirely greyish first segment ; tergites 2-6 shining black on dorsum ; ovipositor (Fig. 57B) moderately large, with base shining black and oval in shape ; piercer yellowish, slightly longer than base, strongly downcurved as seen from side, very broad as seen from ventral (parallel-sided from its base to two-thirds then suddenly tapering to apex).

Length : Body $5 \mathrm{~mm}$; wing $6 \mathrm{~mm}$.

Specimens examined : 1우, Sapporo, Hokkaido, 23. v. 1959 (S. Momoi) ; 1 우, Gamusi, Hokkaido, 12. vii. 1958 (T. Kumata). $8 \sigma^{7} \sigma^{7}$, Mt. Hikosan, Fukuoka Pref., Kyushu, 19. vi. 1985 (R. Morakote) ; 1 우, ditto, 22. vi. 1985 (R. Morakote) ;1우, Mt. Kuju, Oita Pref., 5. vi. 1985 (R. Morakote) ;2우우, Goshikinuma, Urabandai, Fukushima Pref., Honshu, 9. vii. 1985 (R. Morakote).

Host : Unknown.

Distribution : Japan (Honshu, Kyushu), Europe.

Remarks: The ovipositor piercer of the female, which is seen from ventral position, is not described by any authors. Since I found other species that has much the same shape of ovipositor as P.varipes when seen from side but differs when seen from ventral.

\section{Pipunculus thomsoni Becker}

Pipunculus thomsoni Becker, 1897, Berl. ent. Zschr., 42 : 67; -Lundbeck, 1922, Diptera Danica, 4 : 37. — Coe, 1966, Handbk. Ident. Brit. Ins., 10 (2C) : 51. — Kozanék, 1981, Annot. zool. bot. Bratislava, 142 : 14.

Pipunculus pratorum Verrall, 1901, Brit. Flies, 8 : 103.

M ale.

Eyes joined for about length of frontal triangle ; frontal triangle and face silvery pubescence ; antennae all black; third segment oval.

Thorax and scutellum dull black, with brownish dusting on dorsum ; densely coverd with short pale fine hairs ; humeri black; propleural fan with pale pubescence.

Legs with black coxae; femora (Fig. 51C) almost entirely black except extreme one-seventh base and tip yellow ; trochanters, tibiae and tarsi yellow; last tarsal segment black; all femora with two parallel rows of small spines beneath from near base to tip on mid femora, from middle to tip on front and hind femora, four anterior femora almost entirely dull behind, except very narrow posterodorsally shining black ; hind femora almost shining black behind, except narrow posteroventrally.

Wings (Fig. 47C) hyaline, stigma brownish, extending back to tip of Sc, about as 
long as fourth costal section ; r-m situated slightly before basal third of discal medial cell ; last section of vein Ml slightly undulating; halteres and calypteres yellow.

Abdomen as shown in Fig. 51A and B ; densely covered with short pale hairs ; tergite 1 entirely greyish ; tergites 2-4 almost entirely shining black, but with transverse streaks of brownish dusting anteriorly ; tergite 6 black, with obscurely brownish dusting, shorter than tergite 5 , with rather large membranous area ; this area rounding on upperpart then gradually narrowing below, with evidence of small keel at apex.

Genitalia as shown in Fig. $52 \mathrm{~A}-\mathrm{E}$.

Length : Body $5.5 \mathrm{~mm}$; wing $6.5 \mathrm{~mm}$.

\section{Female.}

Frons as that of P.varipes; third antennal segment shortly pointed; tibiae mainly black except basal third yellowish; abdomen with entirely greyish first and second segments ; tergites 3-6 shining black on dorsum, with conspicuous greyish dusting at side ; ovipositor (Fig. 59D and E) moderately large ; base shining black, slightly conical ; piercer rather thick ; almost straight.

Specimens examined : (Hokkaido) $3 \sigma^{7}$, Saroma, Abashiri, 10. vii. 1986 (R. Morakote) ;2 우우, Nukabira, Kamishihoro, Tokachi, 28. vi. 1986 (R. Morakote) ;1 Rebun, 1. viii. 1958 (S. Takagi) ; 16, Rubesu, Kitami, 4-5. vii. 1974 (M. Suwa, T. Kumata and T. Hattori)

Host : Unknown from Japan ; in England as Soleopyx sulphurella (Zetterstedt) by Waloff (1975).

Distribution : Japan (Hokkaido), Europe.

Pipunculus magnicarinatus Morakote, sp. n.

\section{Male.}

Head. Ocellar triangle shining black; eyes joined on upperpart of frons for a distance, slightly shorter than frontal triangle ; frontal triangle silvery at some angle ; face silvery pubescence ; antennae (Fig. 48D) small, all brownish black ; second segment with a few bristles above and beneath ; third segment oval, about 1.5 times as deep as the second.

Thorax and scutellum densely covered with short pale hairs but scarcely seen from dorsal view because of dull brownish dusting on disc ; humeri black.

Legs (Fig. 48E) with black coxae; femora almost entirely black except extreme one-sixth base and tip yellow; trochanters yellow; hind trochanters extending beneath as a triangular projection, tibiae and tarsi extensively yellow ; tibiae with obscurely brownish incomplete ring around middle third from posterior ; all femora with two paralleled-rows of small black spines beneath, from near base to tip on mid femora, after middle to tip on front and hind femora ; front and mid femora with a row of pale pubescence posteromedially from base to tip, those of mid femora are longer ; fore and mid femora almost entirely dull behind ; hind femora polished behind except very narrow posterodorsally dull.

Wings (Fig. 47A) hyaline, slightly tinged with brown, stigma dark brown, extending back to tip of Sc, about twice as long as fourth ; r-m situated slightly after basal third of discal medial cell ; last section of vein Ml rather long, slightly undulating ; 
halteres and calypteres yellow.

Abdomen (Fig. 48A and B) mainly shining black, densely covered with short pale pubescence ; tergite 1 entirely greyish ; tergites $2-5$ with transverse streaks of brownish dusting anteriorly, about less than half of segments, remainder polished black ; tergites 2-5 almost equal in size ; tergite 8 (Fig. 48C) dull brownish dusting, with narrow slot-like membranous area which has a conspicuous large vertical keel medially.

Genitalia as shown in Fig. 53A-D, epandrium and surstyli brownish black ; surstyli symmetrical, rather long and narrow tip.

Length: Body $5 \mathrm{~mm}$; wing $6 \mathrm{~mm}$.

\section{Female.}

Resembling the female of P.varipes but differing by having the ovipositor piercer very thin and wavy as seen from side (Fig. 57F).

Holotype: đ7 (Type No. 2734, Kyushu Univ.), Akankohan, Mt. 0-akan, Kushiro, Hokkaido, 3. vii. 1986 (R. Morakote).

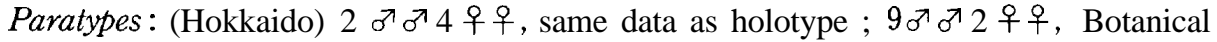
garden, Sapporo, Ishikari, 21. vi. $1986 ; 1 \delta^{\top} 1$ 우, Hitsujigaoka, Sapporo, Ishikari, 21. vi.

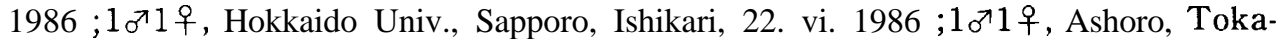
chi, 23. vi. 1986 ; $2 \sigma^{7} 1$ 우, Misumai, Sapporo, Ishikari, 24. vi. 1986 ; 46 이 1 우, Sounkyo, Mt. Daisetsu, Kamikawa, 26. vi. $1986 ; 10 \sigma^{7} \sigma^{7} 6$ 웅. Nukabira, Kamishihoro, Tokachi, 28. vi. 1986 ; $1 \sigma^{7}$, Raus Onsen, Nemuro, 8. vii. 1986 ;36 శ , Saroma, Abashiri, 10. vii. 1986 ; (Honshu) 1ळ , Kadoma, Mt. Hayachine, Iwate Pref., 17. vii. 1985 ; 16, Okurakawa, Mt. Azuma, Fukushima Pref., 10. vii. 1985 ; $1 \sigma^{7}$ Kawaranobo, Mt. Hayachine, Iwate Pref., 16. vii. 1985 ; $1 \sigma^{\nearrow}$, Goshikinuma, Urabandai, Fukushima Pref., 10. vii. 1985 ;1우, Yokomugi, Mt. Adara, Fukushima Pref., 21. vi. 1985 ; (Kyushu) 1ðð , Mt. Kurodake, Oita Pref., 16. vii. 1985. All were collected by R. Morakote. (Hokkaido) 1

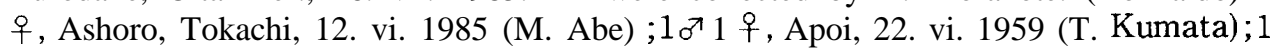
ㄱ, Apoi, 21. vi. 1959 (K. Kamijo) ;1우, Apoi, 22. vi. 1959 (S. Ueda) ;1 $\sigma^{7}$, Rubesu, Shibecha, Nemuro, 25-28. viii. 1971 (K. Yamagishi) ;1 ð, Aka-dake, 1. viii. 1960 (S. Ueda). (Honshu) 107, Mt. Sanageyama, Toyota, Aichi, 18. v. 1972 (T. Tanaka).

Host : Unknown.

Disrtribution: Japan (Hokkaido, Honshu, Kyushu).

Pipunculus subvaripes Morakote, sp. n.

Male.

Eyes joined on upperpart of frons for a distance, slightly longer than frontal triangle; frontal triangle and face silvery at some angle ; antennae with first and second segments black ; third segment yellow, oval, about twice as deep as second segment ; arista black, slightly longer than the third.

Thorax extensively shining black on dorsum, but with greyish dusting near margin, densely covered with short pale hairs ; scutellum with greyish dusting; humeri black; propleural fan pale.

Legs all yellow, except coxae and last tarsal segments black; all femora with two parallel rows of small black spines beneath from near base to tip on mid femora, from 
middle to tip on front and hind femora ; pulvilli slightly smaller than last tarsal segment.

Wings (Fig. 47D) hyaline, stigma brownish, extending back to tip of Sc, slightly longer than fourth costal section; $r-m$ situated at basal third of discal medial cell ; last section of vein Ml moderately undulating; halteres and calypteres yellow.

Abdomen as shown in Fig. 49A and B ; tergite 1 entirely greyish ; tergite 2 entirely clothed with brownish; tergites 3-5 with transverse streaks of brownish dusting, about anterior half, remainder shining black ; tergite 8 black, with obscurely brownish dusting, very large, slightly longer than tergite 5, with narrow slot-like membranous area at middle ; this area with a distinct keel at middle.

Genitalia as shown in Fig. 55A-F ; epandrium almost as wide as long ; surstyli widening at basal half, then suddenly narrowing to tip.

Length : Body $4.5 \mathrm{~mm}$; wing $5.5 \mathrm{~mm}$.

\section{Female.}

Differing from the female of P.varipes by having the legs entirely yellow and the ovipositor piercer tapering when seen from ventral (Fig. 57C).

Holotype: $0^{7}$ (Type No. 2735, Kyushu Univ.), Yunohana, Tateiwa-mura, Fukushima Pref., Honshu, 14. vii. 1985 (R. Morakote).

Paratypes: (Honshu) $2 \sigma^{7} \sigma^{7}$, same data as holotype ; 16, Boudo-toge, Asahimura, Niigata Pref., 2. vii. 1985 ; (Kyushu) 1ðð , Mt. Hikosan, Fukuoka Pref., 19. vi. 1985 ; (Honshu) 1 $10^{7}$, Goshikinuma, Urabandai, Fukushima Pref., 9. vii. 1985 ;1 $\sigma^{7}$, Hosono, Mt. Okubandai, Fukushima Pref., 9 vii. 1985 ; (Hokkaido) 2 우우, Raus Onsen, Nemuro, 8. vii. 1986 ; all were collected by R. Morakote ; $1 \sigma^{7}$, Akadake, Hokkaido, 1. vii, 1960 (S. Ueda) ;1우, Gamushi, Hokkaido, 12. vii. 1958 (T. Kumata) ;1우, Sapporo, Hokkaido, 1958 (S. Momoi) ;1ð Atsushabe, 14. ix. 1958 (S. Takagi).

Host : Unknown.

Distribution : Japan (Hokkaido, Honshu).

\section{Pipunculus oldenbergi Collin}

Pipunculus oldenbergi Collin, 1956, Opus. Ent., 21: 163. —Kozanék, 1981, Annot. zool. bot. Bratislava, $142: 12$.

\section{$M$ ale.}

Eyes joined on upperpart of frons for about as long as frontal triangle, antennae all black, third segment shortly pointed, about twice as deep as second segment.

Thorax extensively covered with brownish dusting and short pale fine hairs on dorsum ; scutellum shining black on posterior half ; humeri black.

Legs almost entirely black, except extreme tip of femora (Fig. 50G) and basal third of tibiae ; trochanters simple ; mid and hind femora with two serrulated rows of small black spines beneath from near base to tip on mid femora, from middle to tip on hind femora ; four anterior femora almost entirely black behind ; hind femora shining black behind, at least lower half ; hind tibiae with 2-3 bristles at middle anteriorly.

Wings (Fig. 47B) hyaline, stigma dark brown, extending back to tip of S C, slightly longer than fourth costal section; r-m situated about one-third of discal cell ; last 
section of vein $\mathrm{Ml}$ very undulating.

Abdomen (Fig. 50A) with tergite 1 entirely greyish; tergites 2-5 mainly shining black on dorsum but greyish at sides, anterior margin with brownish dusting; all tergites densely covered with short pale fine hairs; tergite 8 (Fig. 51F) brownish dusting, roughly triangular shape, almost as long as tergite 5 , with moderately large oval membranous area at the right side of apex.

Genitalia as shown in Fig. 50C and D.

Length : Body $5.5 \mathrm{~mm}$; wing $6.5 \mathrm{~mm}$.

Specimens examined : (Hokkaido) 56 శ , Nukabira, Kamishihoro, 29. vi. $1986 ; 10^{7}$, Hitsujigaoka, Sapporo, Ishikari, 23. vi. $1986 ; 4$ व $^{7}$ व , Ashoro, Tokachi, 29. vi. $1986 ; 10^{7}$, Akankohan, Mt. 0-akan, Kushiro, 4. vii. 1986 ; all were collected by R. Morakote. $1 \sigma^{7}$, Obihiro, 15. vii. 1966 (M. Suwa). (Honshu) 1우,Hanno, Saitama, 2. v. 1968 (H. Takizawa).

Host : Unknown.

Distribution: Japan (Hokkaido, Honshu), Europe.

Pipunculus diuteus Morakote, sp. n.

\section{Female.}

This species is very much similar to P.varipes but different from it as follows : larger ; stigma long, about twice as long as fourth costal section, last section of vein Ml of wings very slightly undulating ; ovipositor (Fig. 58A and B) with greatly long tapering piercer which apex extending back to anterior margin of first segment ; ovipositor base slightly elongate, piercer yellow, moderately downcurved, about twice, or slightly more than twice as long as base.

Length : Body $6 \mathrm{~mm}$; wing $7 \mathrm{~mm}$.

Holotype:우 (Type No. 2736, Kyushu Univ.), Kawaranobo, Mt. Hayachine, Iwate Pref., Honshu, 17. vii. 1985 (R. Morakote).

Paratype: 1 우, same data as holotype.

Remarks : This species has the ovipositor very similar to the European species $P$. zugmayeriae Kowarz but other characters such as wings and legs are clearly different from it.

H ost : Unknown.

Distribution : Japan (Hokkaido, Kyushu).

Pipunculus auius Morakote, sp. n.

\section{Female.}

This species is closely related to P.varipes but different from other species as follows : Femora entirely yellow ; third costal section of wing about 1.5 times as long as fourth ; femora all brightly 'yellow ; ovipositor piercer (Fig. 58D) about 1.5 times as long as ovipositor base, moderately downcurved.

Length : Body $5.7 \mathrm{~mm}$; wing $6.5 \mathrm{~mm}$.

Holotype:우 (Type No. 2737, Kyushu Univ.), Saroma, Abashiri, Hokkaido, 10. vii. 1986 (R. Morakote).

Paratypes: (Hokkaido) 3우우, same data as holotype ; 1 우, Hitsujigaoka, Sapporo, 
Ishikari, 23. vi. 1986 ;1우 Nukabira, Kamishihoro, Tokachi, 28. vi. 1986 ;1우, Akankohan, Mt. 0-akan, Kushiro, 3. vii. 1986 ; (Honshu) 1우, Kawaranobo, Mt. Hayachine, Iwate Pref., 17. vii. 1985 ;1우, Kadoma, Mt. Hayachine, Iwate Pref., 17. vii. 1985 ; all were collected by R. Morakote ;1우, Apoi-dake, Hokkaido, 21. vi. 1959 (S. Ueda) ; 1 우 same location, 10. vii. 1966 (M. Suwa).

Host : Unknown.

Distribution : Japan (Hokkaido, Honshu).

Pipunculus babai Morakote, sp. n.

\section{Female (Fig. 56).}

Rather small in size ; ocellar triangle shining black ; frons and occiput cinereous, the former wide, slightly convex at middle third, with a row of very short hairs along each lateral margin ; antenna with first and second segments brownish black; third antennal segment yellowish, oval, about 1.5 times as deep as second segment.

Thorax and scutellum densely covered with short pale hairs on dorsum, extensively shining black, except back of humeri along sides to base of wings greyish ; humeri dull black.

Legs brightly yellow, except coxae and last tarsal segments black ; trochanters simple ; all femora with two serrulated rows of small black spines beneath, from near base to tip on mid femora, from after middle to tip on fore and hind femora.

Wings rather clear, noticeably broadened on apical half ; stigma light brown, extending back to base of $\mathrm{Sc}$, about as long as fourth costal section, last section of vein Ml very undulating.

Abdomen with entirely greyish first tergite ; tergites 2-6 extensively shining black on dorsum, conspicuously greyish at side ; ovipositor (Fig. 57G and $\mathrm{H}$ ) rather small ; ovipositor base oval, shining brownish black ; ovipositor piercer about 1.3 times as long as base, yellowish, very thin and slightly downcurved as seen from side.

Length : Body $4.2 \mathrm{~mm}$; wing $5.7 \mathrm{~mm}$.

Holotype:우 (Type No. 2738, Kyushu Univ.), Boudo-toge, Asahimura, Niigata Pref., Honshu, 2. vii. 1985 (R. Morakote).

Paratypes: 1 우, Mt. Hikosan, Fukuoka Pref., Kyushu, 10. vii. 1986 (R. Morakote) ; 1우, Gamushi, Hokkaido, 12. vii. 1958 (T. Kumata) ; 1 우, Rubesu, Shibetsu, Nemuro, Hokkaido, 15-28. viii. 1971 (K. Yamagishi).

Host : Unknown.

Distribution: Japan (Hokkaido, Honshu, Kyushu).

\section{Pipunculus campes tris Latreille}

Pipunculus campestris Latreille, 1804, Hist. Nat. Ins., 14 : 392. — Verrall, 1901, Brit. Flies, 8 : 99. — Coe, 1966, Handbk. Ident. Brit. Ins., 10(2C): 53. — Kozanék, 1981, Annot. zool. bot. Bratislava, $142: 5$.

\section{F emale.}

Rather small in size ; head quite similar to that of $P$. babai except antennae all black, third segment shortly pointed. 
Thorax and scutellum extensively clothed with brownish to greyish dusting and densely short pubescence; humeri dull luteous.

Legs with black coxae, trochanters dark brown, simple in shape ; all femora almost entirely black except extreme base and tip yellow ; fore and mid femora extensively dull but hind femora extensively shining black behind; tibiae and tarsi dark brown, last tarsal segments black; pulvilli brigthly yellow, slightly longer than last tarsal segments.

Wings hyaline, stigma light brown, extending back to tip of Sc, about as long as fourth costal section, r-m situated slightly before basal third of discal medial cell ; last section of vein $\mathrm{Ml}$ very undulating.

Abdomen with tergites 1 and 2 entirely greyish ; tergites 3-6 shining black on dorsum, greyish at sides ; all tergites densely covered with short pale hairs ; ovipositor (Fig. 60A and B) with conical shining black base ; ovipositor piercer rather thick, slightly downcurved and longer than ovipositor base.

Length : Body $4.2 \mathrm{~mm}$; wing $5.2 \mathrm{~mm}$.

Specimens examined : (Hokkaido) 2 우우, Akankohan, Mt. 0-akan, 3. vii. 1986 (R. Morakote) ;1우, Ashoro, Tokachi, 28. vi. 1986 (R. Morakote) ; 1 우, same location, 12. vi. 1986 (M. Abe) ; 1 우, Shibecha, Kushiro, 16. vi. 1986 (M. Abe) ;1우, Obihiro, 15. vii. 1966 (M. Suwa). (Honshu) 1 우, Tadeshina-kogen, Nagano, 13. viii. 1963 (T. Okadome).

Host : Unknown from Japan in Germany Macrosteles laevis (Ribaut), Arthaldeus pascuellus (Fallen), and Cicadula quadrinotata (Fabricius) ; in England Macrosteles laevis (Ribaut), M. sexnotatus (Fallen), Diplocolenus bensoni (China), Errastunus ocellar. is (Fallen), Eucelis obsoletus (Kirschbaum), E. plebejus (Fallen), Psammotettix confinis (Dahlbom) ; and in Poland Macrosteles laevis (Ribaut). (see Freytag, 1985).

Distribution : Japan (Hokkaido), Europe.

Pipunculus rarus Morakote, sp. n.

F emale.

Mostly resembling $P$. campestris Latreille but differing as follows : Femora mainly dark brown except base and tip yellow ; ovipositor (Fig. 60C and D) with base rather short, conical shape ; ovipositor piercer moderately thickened and downcurved, about 1.5 times as long as ovipositor base.

Length : Body $4 \mathrm{~mm}$; wing $4.8 \mathrm{~mm}$.

Holotype:우 (Type No. 2739, Kyushu Univ.), Yunohana, Taiwa-mura, Fukushima Pref., 14. vii. 1985 (R. Morakote).

Paratype:1우, Sapporo, Hokkaido, 28. v. 1959 (S. Ueda).

Host : Unknown.

Distribution : Japan (Hokkaido, Honshu).

Pipunculus nitor Morakote, sp. n.

Female.

Ocellar triangle shining black, frons almost parallel-sided, entirely cinereous, with a row of short pale hairs along each lateral margin; antennae dull brownish black, second segment with a few short bristles above and longer beneath, third segment 
shortly pointed, about twice as deep as second.

Thorax and scutellum dull with brownish dusting on dorsum except notopleuron cinereous, densely covered with short pale hairs but scarcely seen ; humeri dull luteous ; pleurae cinereous ; propleurae with a brush of about 10-13 long pale pubescence.

Legs with black coxae; femora mainly brownish black except basal third and apical tip yellowish ; trochanters, tibiae and tarsi yellow except last tarsal segment black ; pulvilli and claws enlarged, about twice as long as last tarsal segment.

Wings hyaline, slightly tinged with brown ; stigma dark brown, extending back to tip of Sc, about 1.3 times as long as fourth costal section, r-m situated slightly before basal third of discal medial cell, last section of vein Ml slightly undulating.

Abdomen densely covered with short pale pubescence; tergite 1 and 2 entirely greyish ; tergites 3-5 shining black on dorsum but conspicuous greyish at side ; ovipositor (Fig. 59A and B) moderately large ; ovipositor base shining black and oval in shape ; ovipositor piercer strong and rather thick, straight, about 1.3 times as long as base, shining brownish black.

Length : Body $4 \mathrm{~mm}$; wing $5.2 \mathrm{~mm}$.

Holotype:우 (Type No. 2740, Kyushu Univ.), Mt. Kuju, Oita Pref., Kyushu, 28. v. 1986 (R. Morakote).

Paratypes: 2 우우, Mt. Hikosan, Fukuoka Pref., 22. v. 1986 (R. Morakote).

Host : Unknown.

Distribution: Japan (Kyushu).

Remarks : This species has the ovipositor which very much resembles the European species P.spinipes Meigen but other characters such as antennae and legs are clearly different from it.

\section{Pipunculus boharti (Hardy)}

Dorilas (Dorilas) boharti Hardy, 1948, The Wasmann Collector, 7(4): 131.

Host : Unknown.

Distribution: Japan (Okinawa).

Remarks : After Hardy (1948) described both male and female of this species, it has no information of this species till now. 

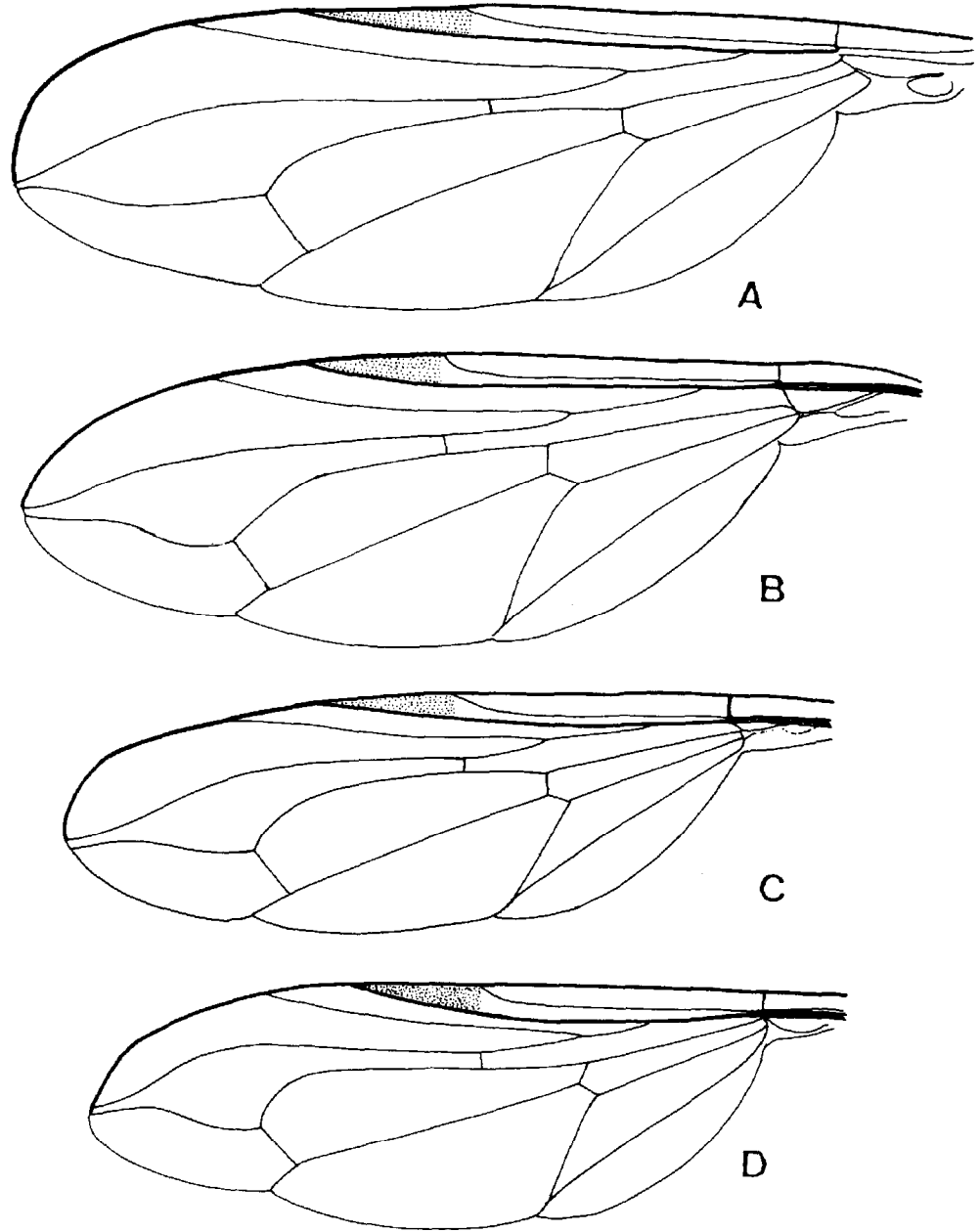

Fig. 47. Wings of Pipunculus spp: A. magnicarinatus Morakote, sp. n. B. oldenbergi Collin ; C. thomsoni Becker; D. subvaripes Morakote, sp., n. 


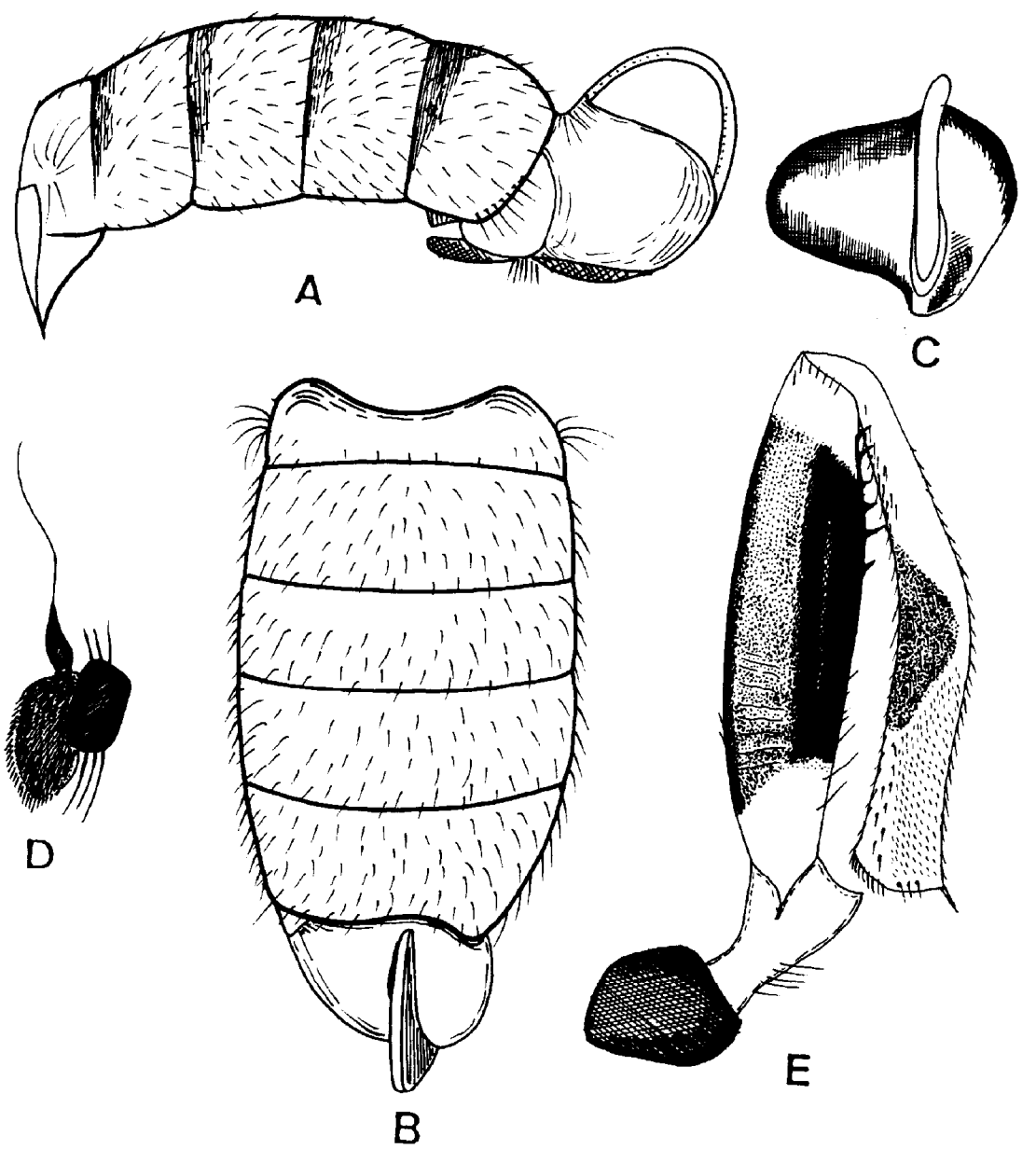

Fig. 48. Pipunculus magnicarinatus Morakote, sp. n. (male) : A and B. Abdomen (A. lateral, B. dorsal) ; C. segment 8, behind ; D. antenna ; E. femora, lateral. 


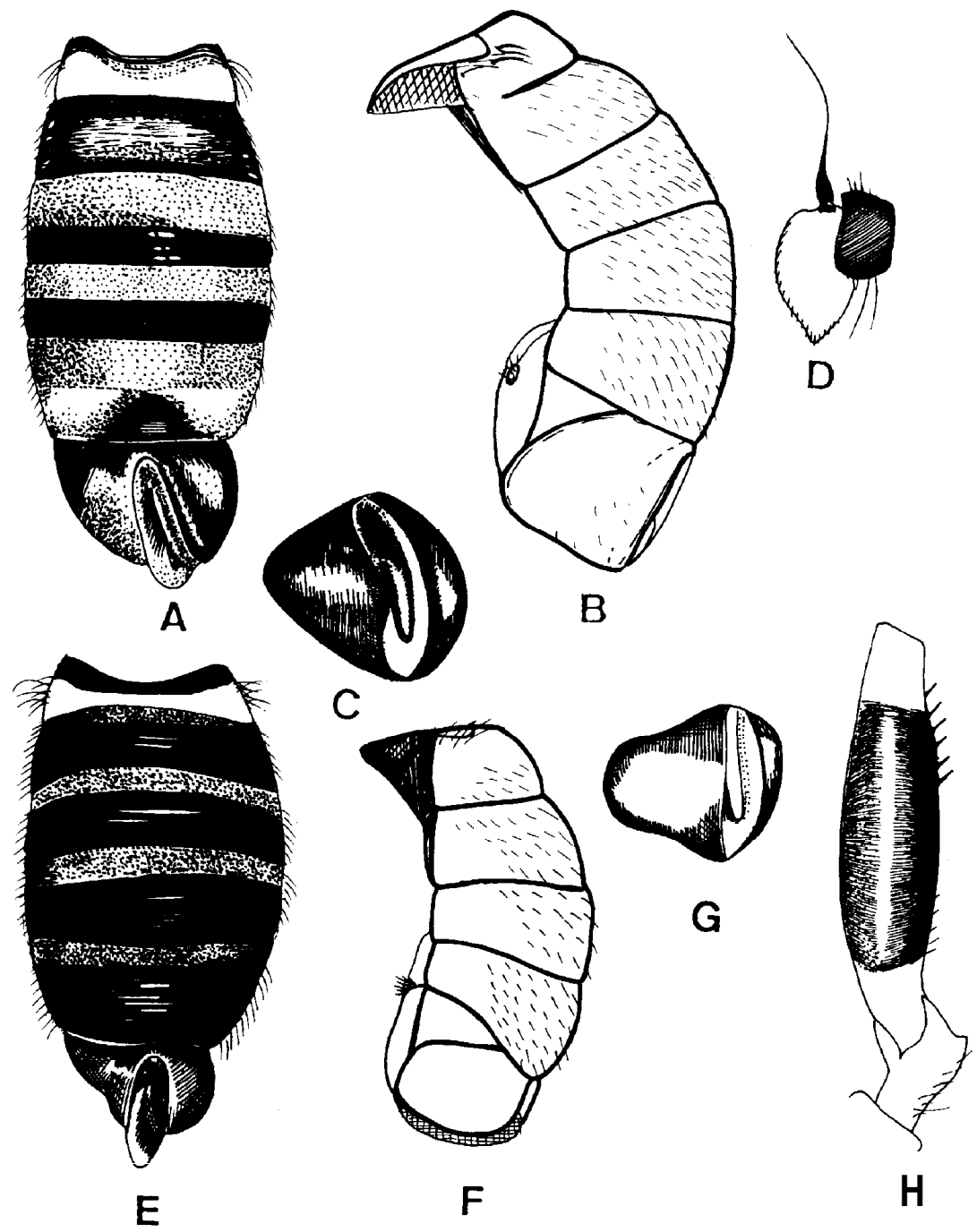

Fig. 49. A-D. Pipunculus subvaripes Morakote, sp. n. (male) : A and B. Abdomen (A. dorsal, B. lateral) ; C. segment 8, behind ; D. antenna. E-H. P. varipes Meigen (male) : E and F. Abdomen (E. dorsal, F. lateral) ; G. segment 8, hehind ; H. femora. 


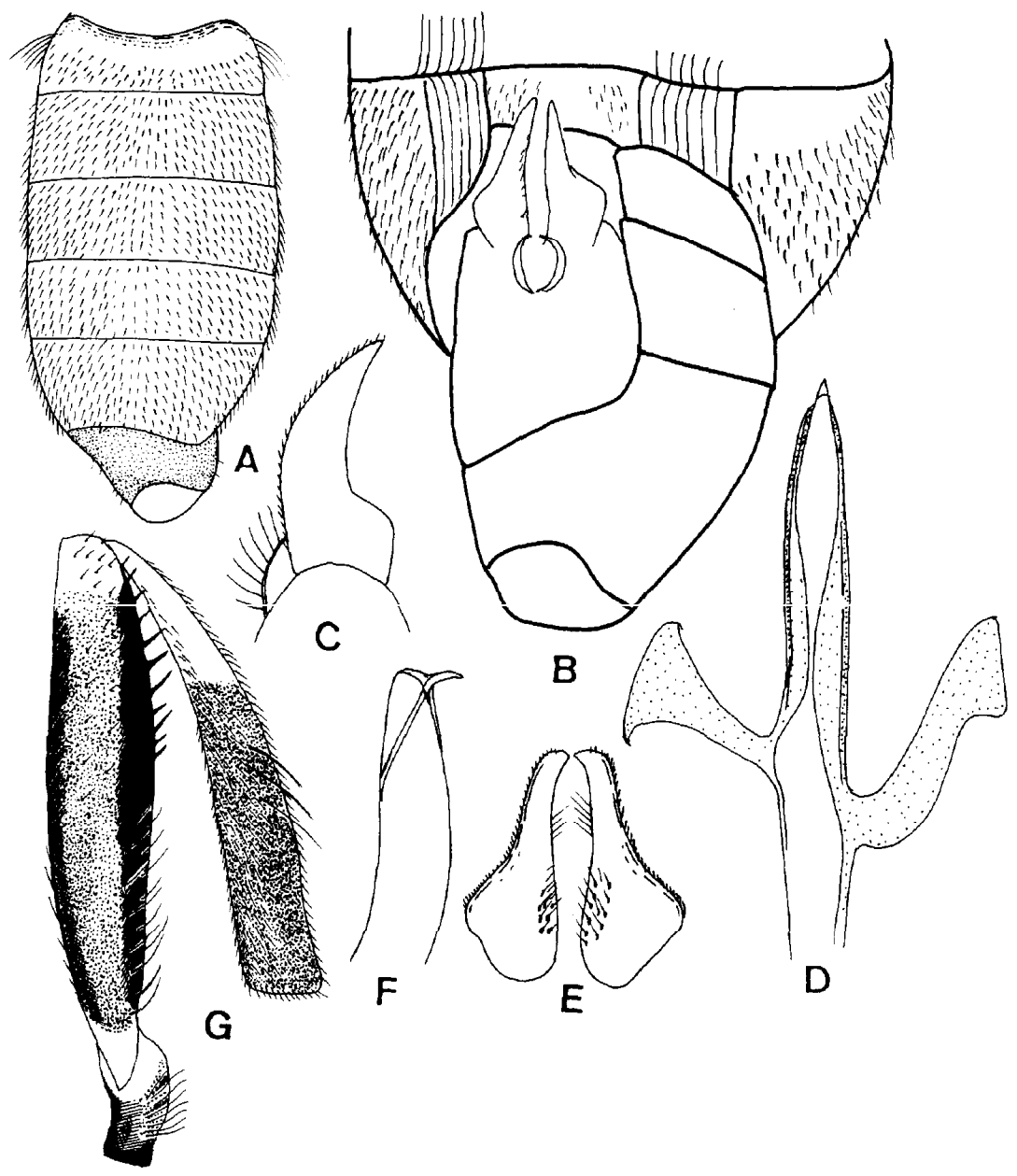

Fig. 50. Pipunculus oldenbergi Collin (male) : A. Abdomen, dorsal ; B. abdominal terminalia, ventral ; C. surstylus, lateral ; D. aedeagal supporter, dorsal ; E. surstylus, ventral ; F. apex of aedeagal supporter, lateral ; G. femora, lateral. 


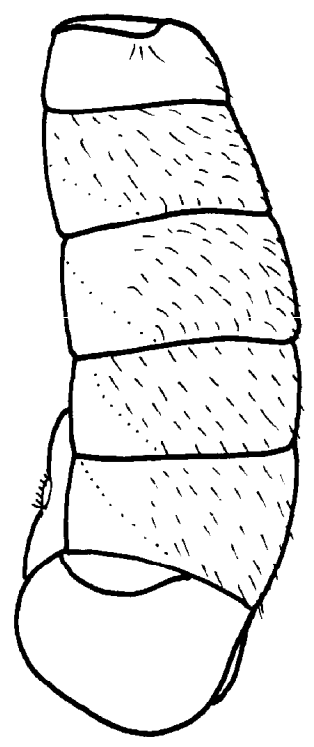

A

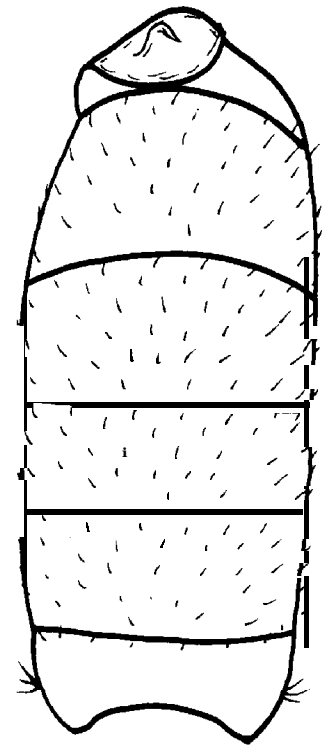

B
E

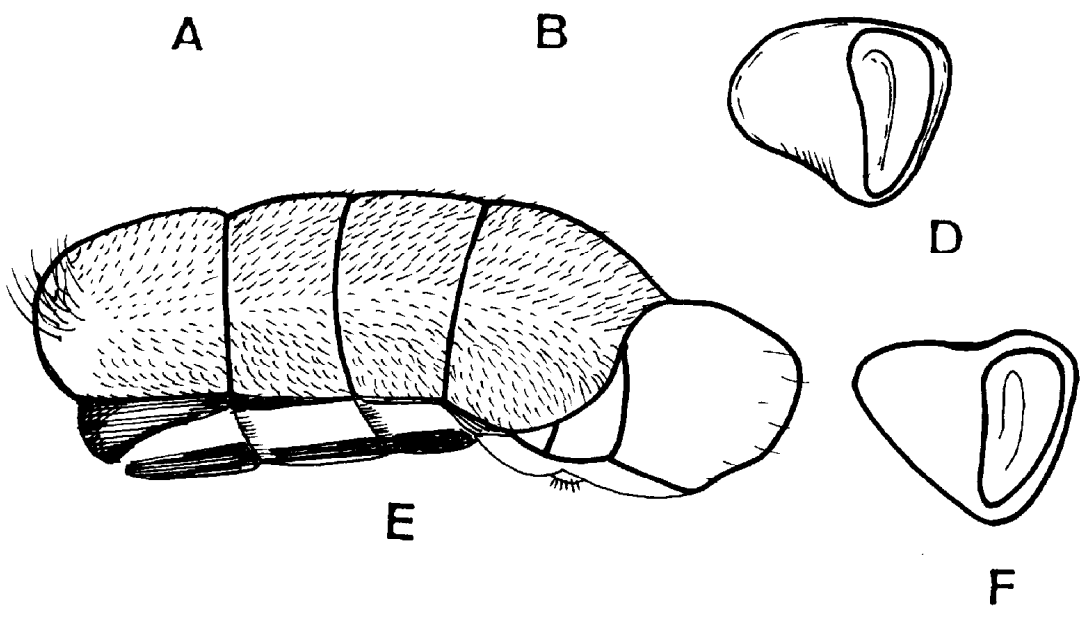

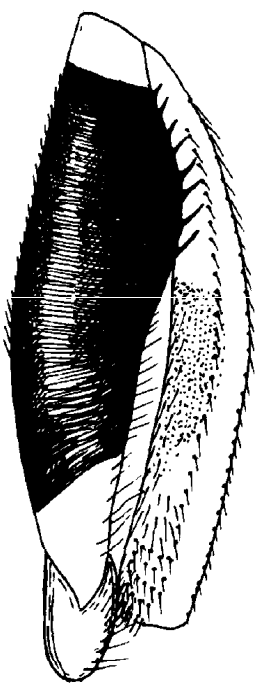

C

Fig. 51. A-D. Pipunculus thomsoni Becker: A and B. Abdomen (A. left side, B . dorsal) ; C. hind leg, anterior ; D. segment 8, behind. E-F. F'. oldenbergi Collin : E. Abdomen, left side ; F. segment 8, hehind. 

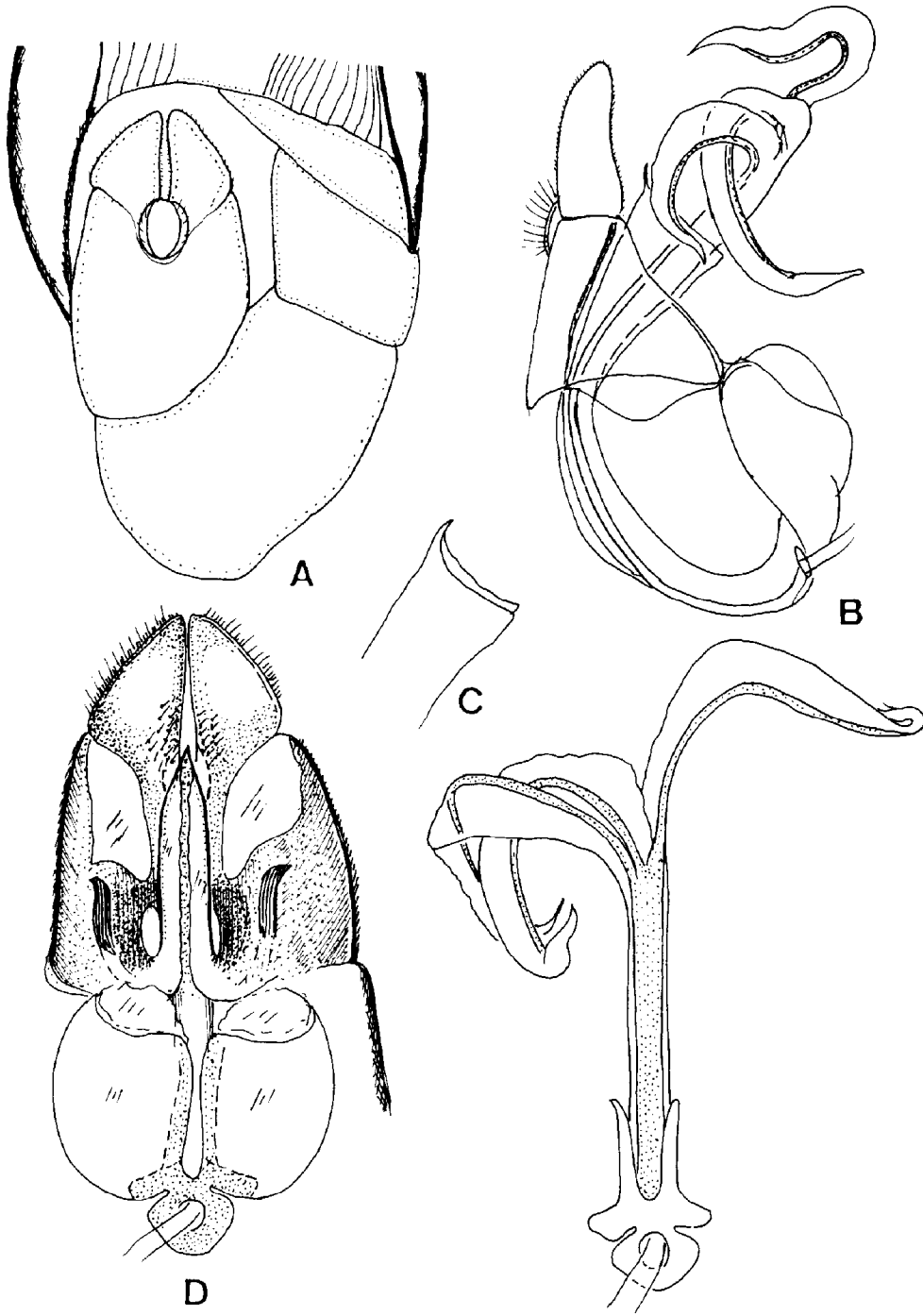

E

Fig. 52. Pipunculusthomsoni Becker: A. Abdominal terminalia, ventral ; B. genitalia, lateral ; C. apex of adeagal supporter, lateral ; D. genitalia, lateral, E. aedeagus, ventral. 


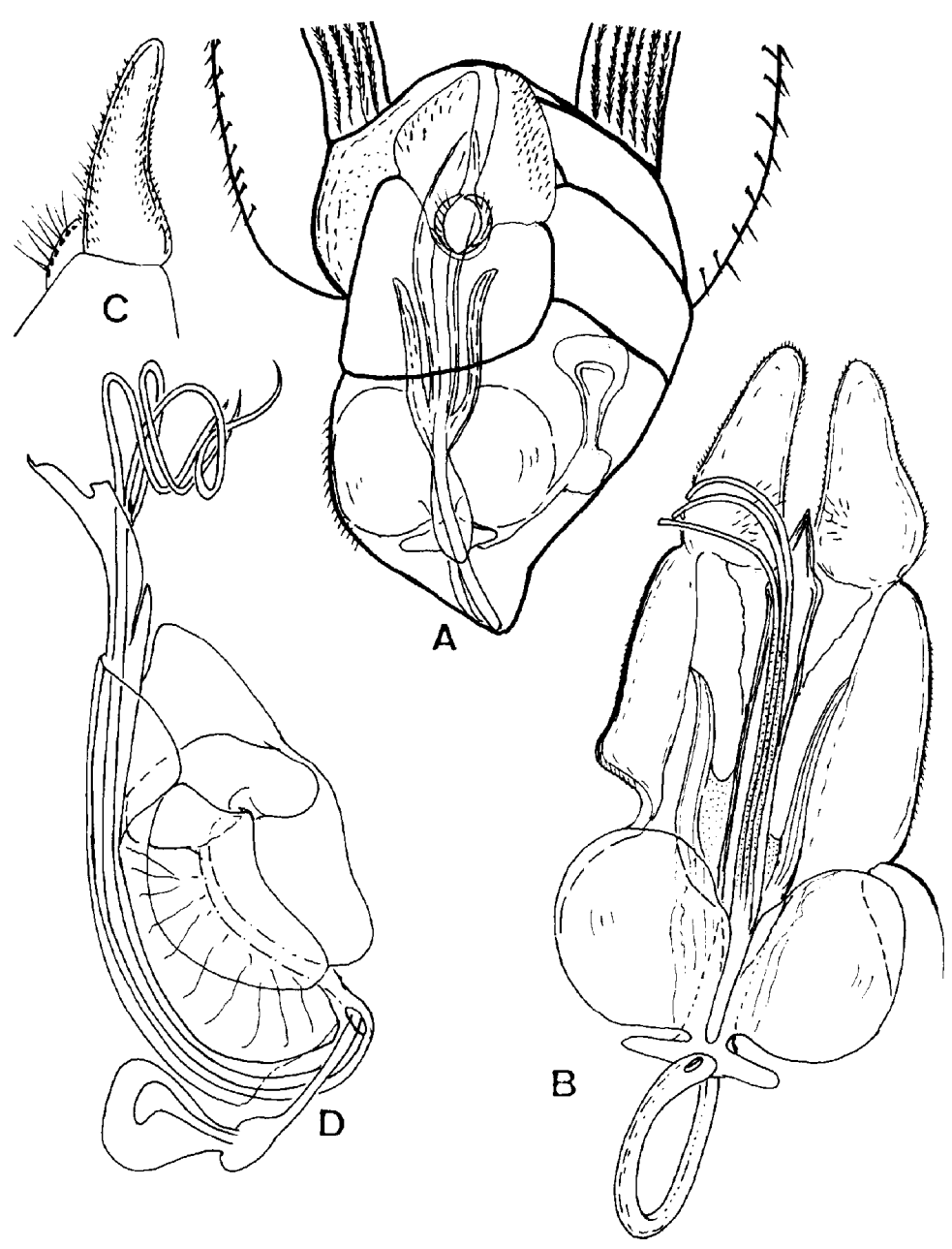

Fig. 53. Pipunculus magnicarinatus Morakote, sp. n. : A. Abdominal terminalia, ventral ; B. genitalia, dorsal ; C. surstylus, lateral ; D. genitalia, lateral. 


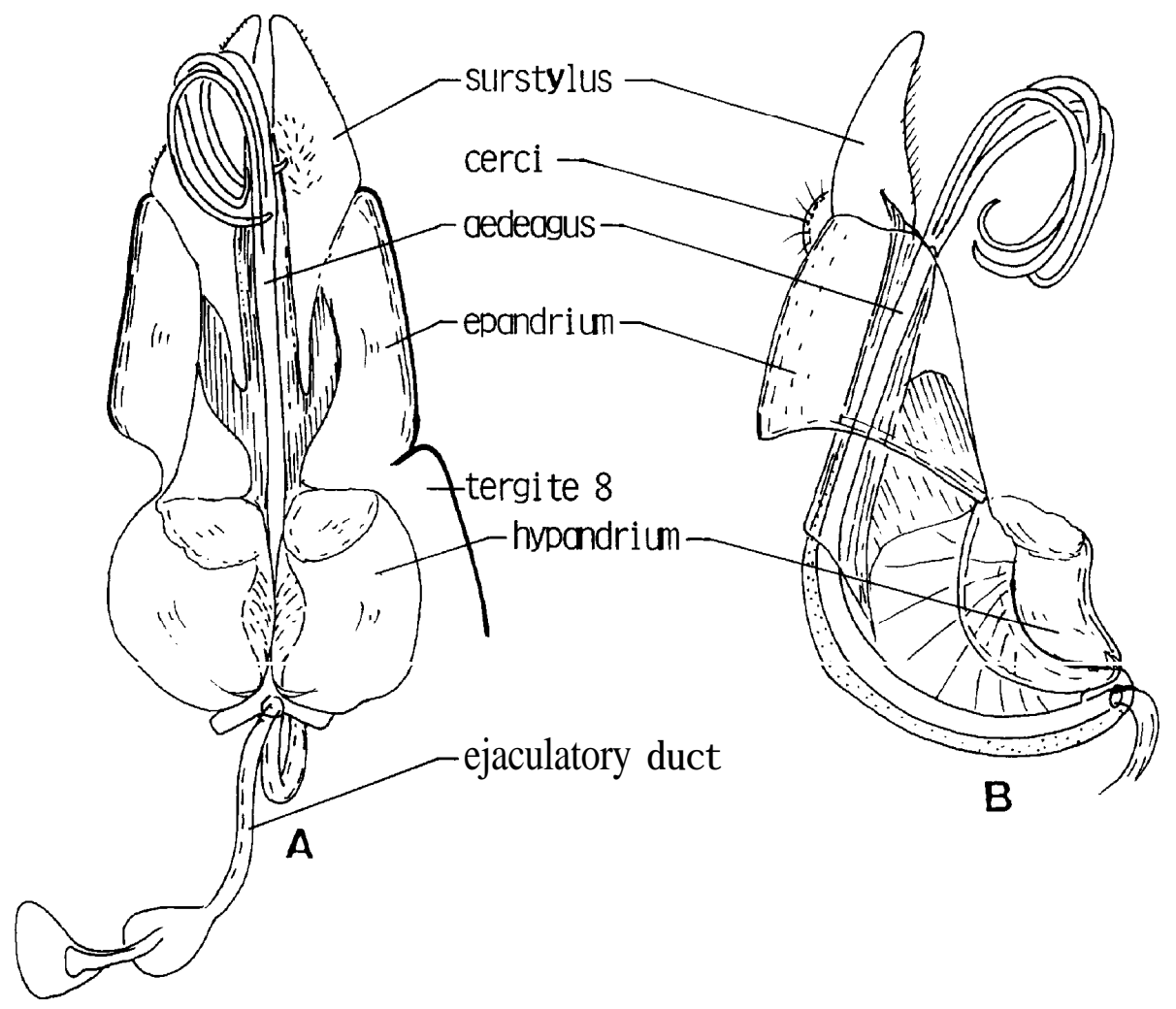

Fig. 54. Male genitalia of Pipunculusvaripes Meigen: A. Dorsal, B. ventral. 


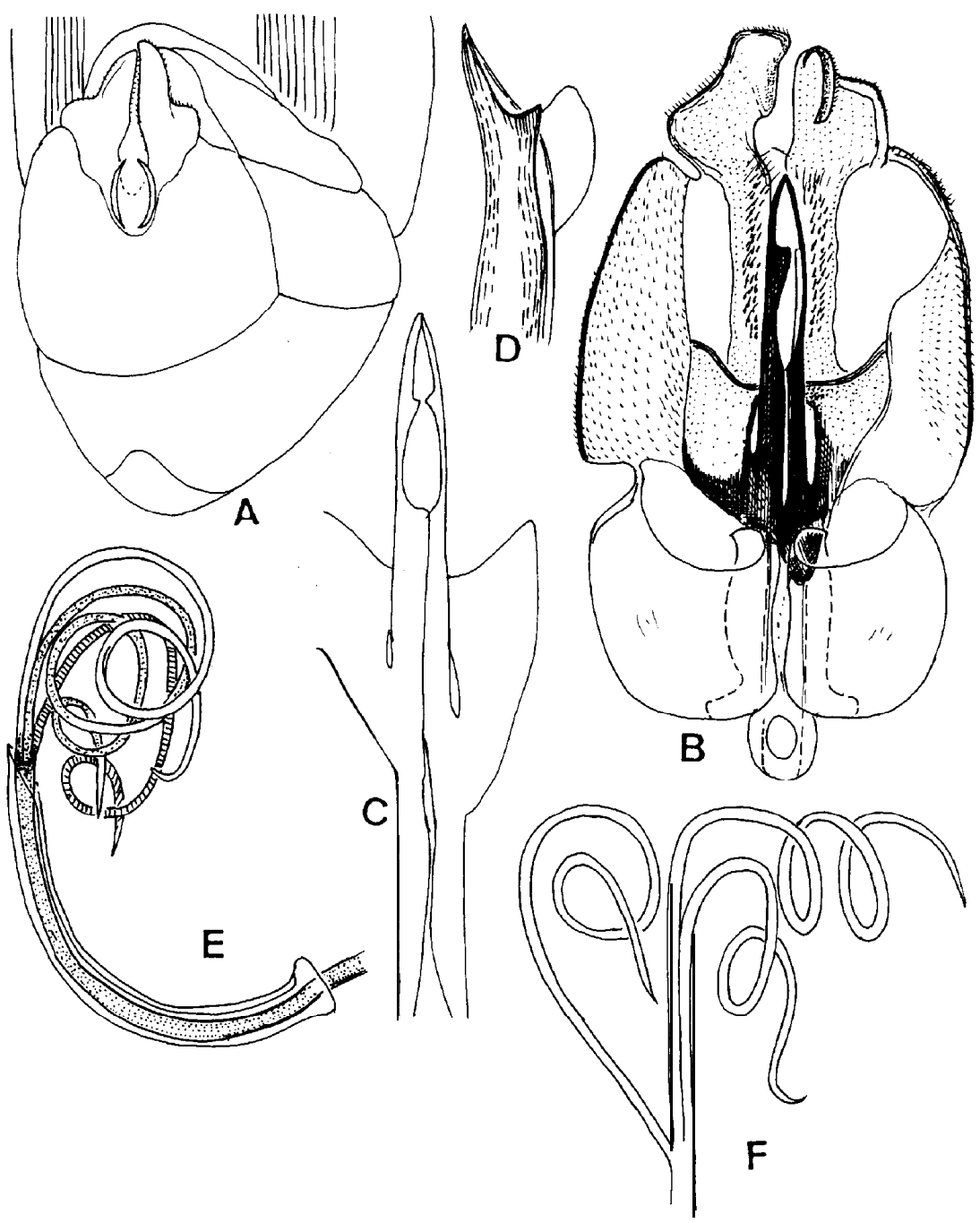

Fig. 55. Pipunculus subvaripes Morakote, sp. n. (male) : A. abdominal terminalia, ventral ; B. genitalia, dorsal ; aedeagal supporter ; D. apex of aedeagal supporter, lateral ; E and F. aedeagus (E. lateral, F. dorsal). 


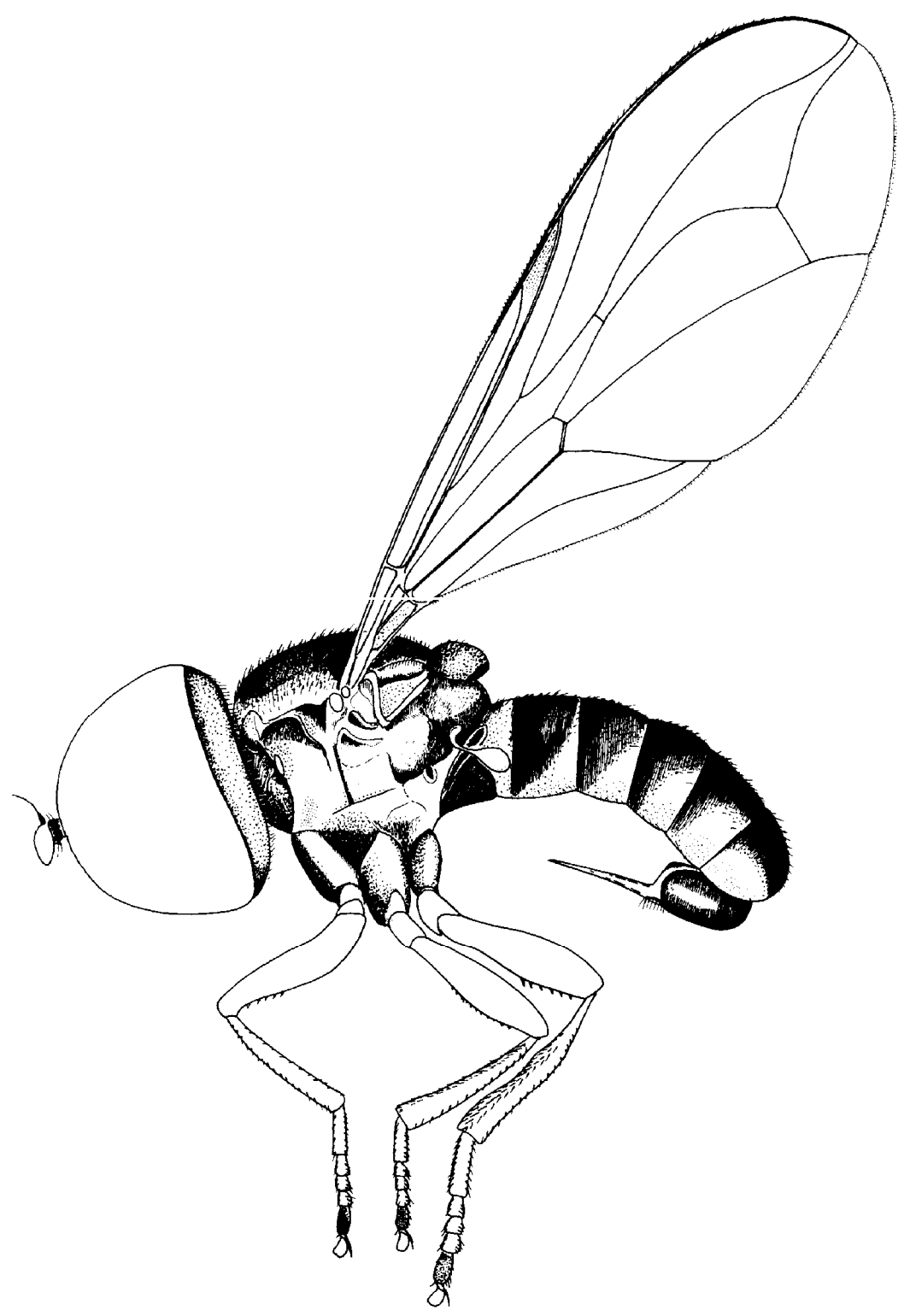

Fig. 56. Pipunculus babai Morakote, sp. n. (female). 

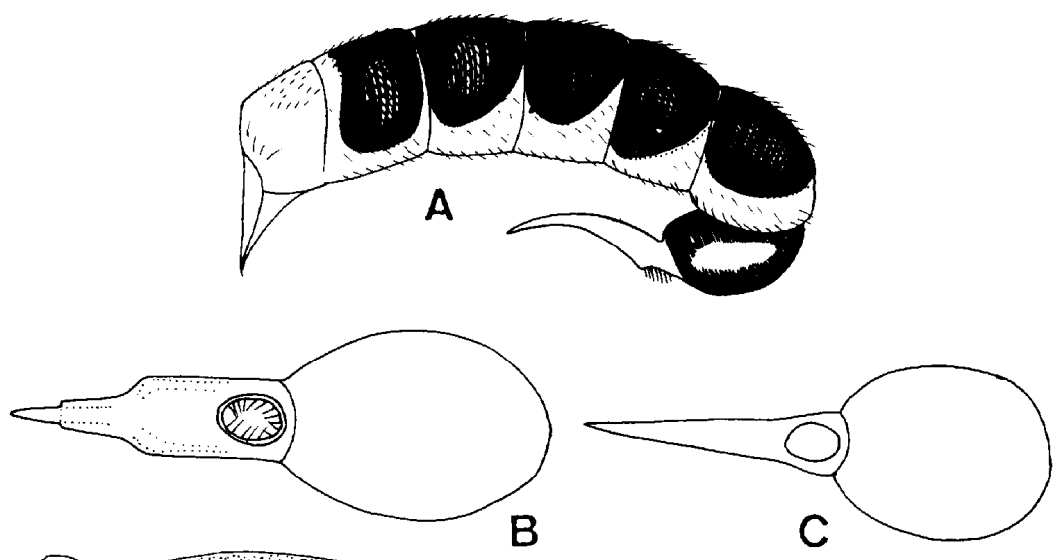
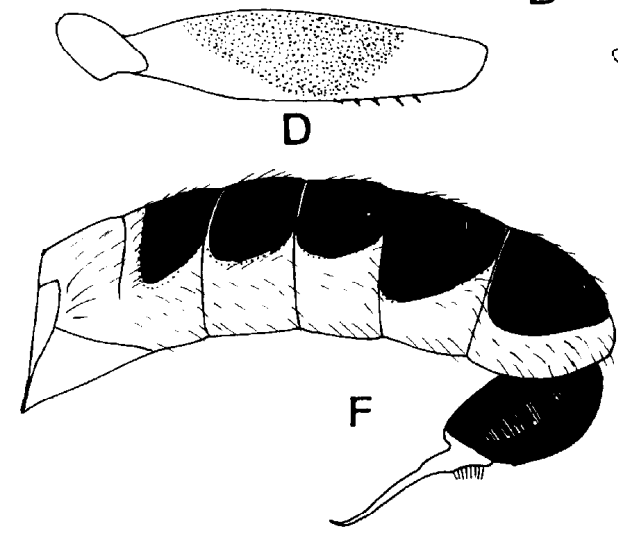

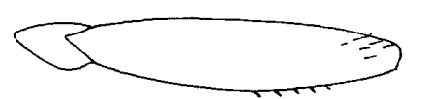

$E$

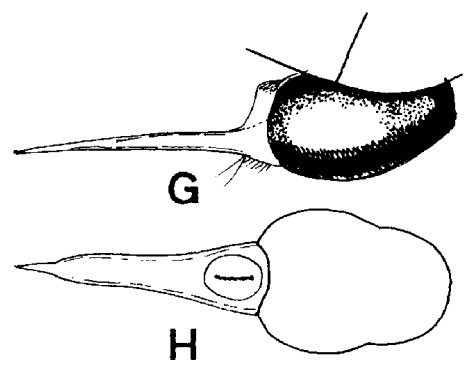

Fig. 57. A, C and E. Pipunculus subvaripes Morakote, sp. n. (female) : A. Abdomen, lateral ; C. ovipositor, ventral ; E. femur, anterior. B and D. P.varipes Meigen (female) : B. ovipositor, ventral ; D. femur, anterior. F. Female abdomen of $P$. magnicarinatus Morakote, sp. n. G-H. Ovipositor of P. babai Morakote, sp. n. : G. lateral, H. ventral. 

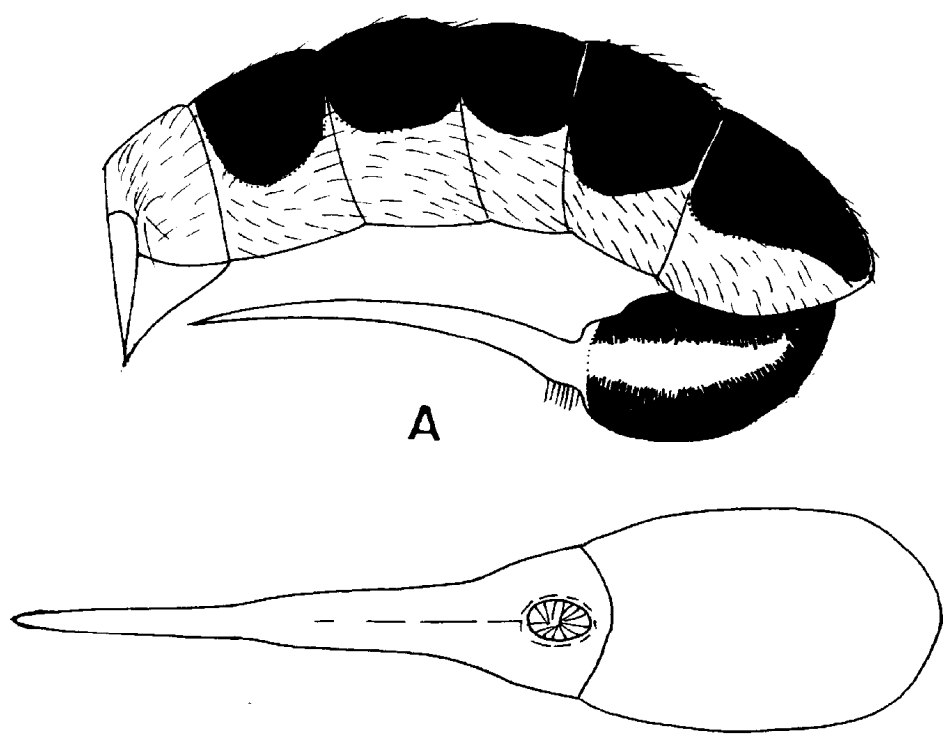

$\mathrm{B}$
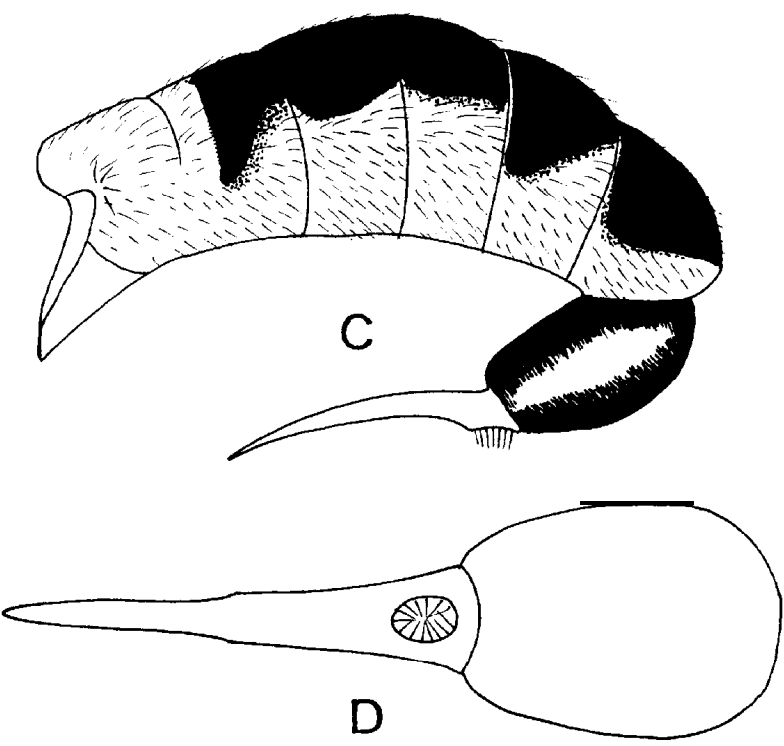

Fig. 58. A and B. Pipunculus diuteus Morakote, sp. n. (female) : A. Abdomen, lateral ; B. ovipositor, ventral. C and D. P. avius Morakote, sp. n. (female) : C. Abdomen, lateral ; D. ovipositor, ventral. 


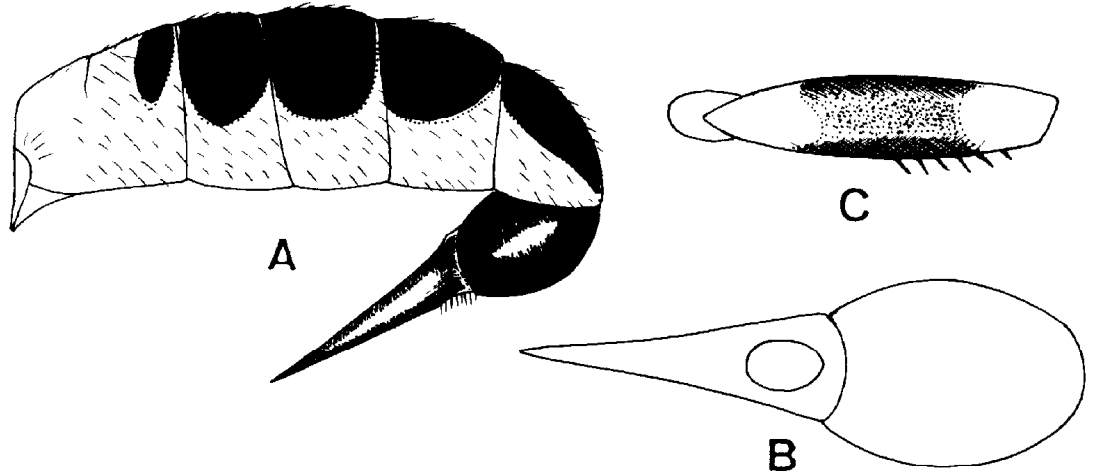

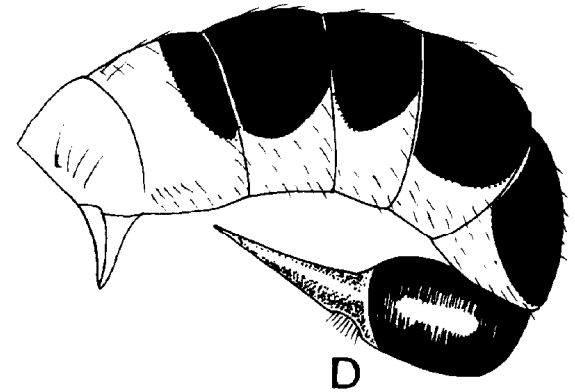

D

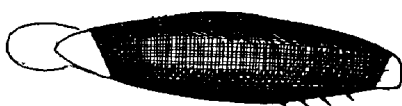

F

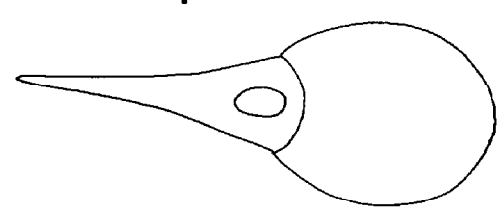

$E$

Fig. 59. A-C. Pipunculus nitor Morakote, sp. n. (female) : A. Abdomen, lateral ; B. ovipositor, ventral ; C. hind femur, anterior. D-F. P.thomsoni Morakote, sp. n. (female) : D. abdomen, lateral ; E. ovipositor, ventral ; F. hind femur, anterior. 


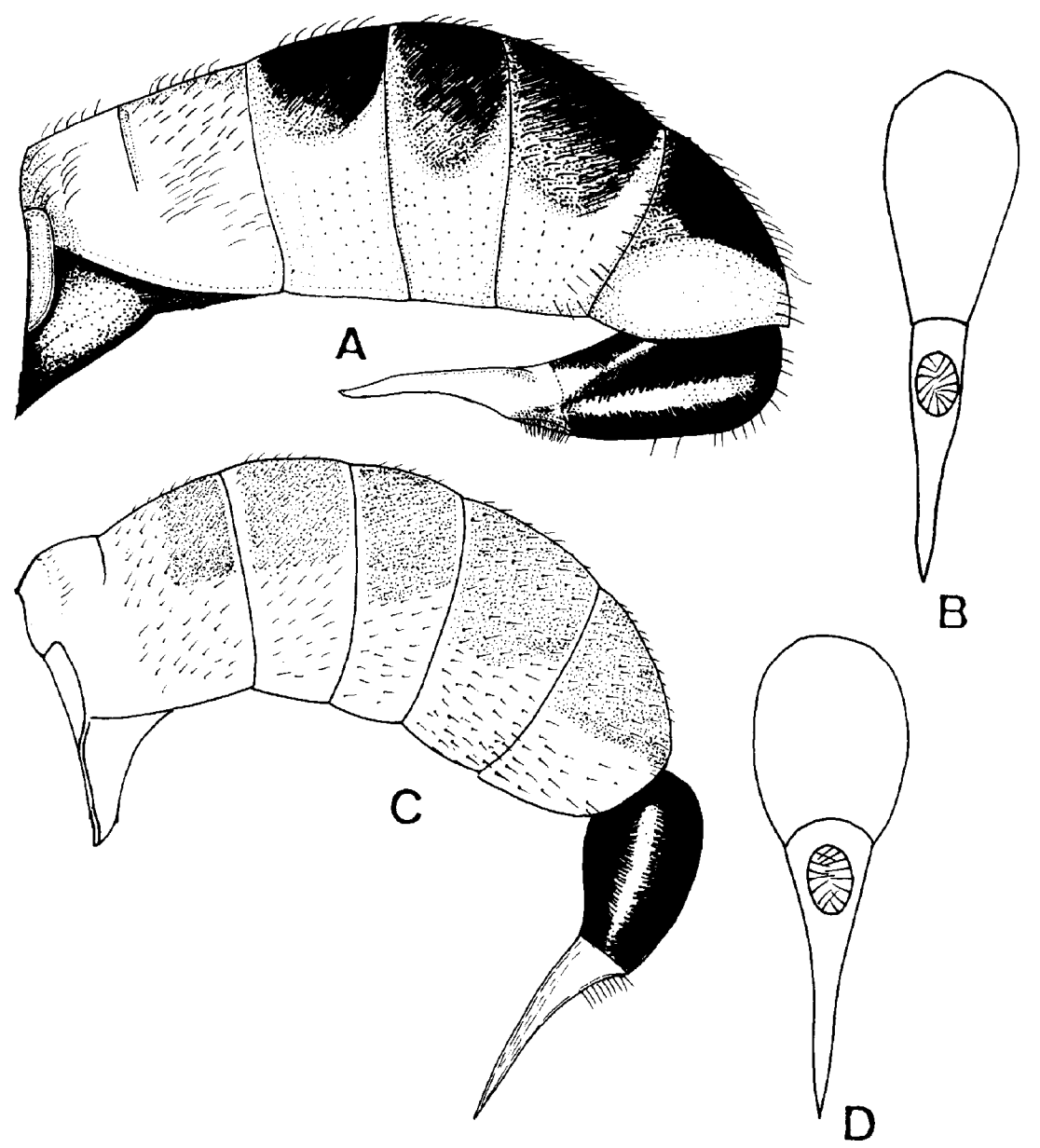

Fig. 60. A and B. Pipunculus campestris Latreille (female) : A. Abdomen, lateral ; B. ovipositor, ventral. C and D. P.rarus Morakote, sp. n. (female) : C. abdomen, lateral ; D. ovipositor, ventral. 